\title{
Immunofluorescent staining for the detection of Treponema pallidum in early syphilitic lesions
}

\author{
A. E. WILKINSON AND L. P. COWELL \\ Venereal Diseases Reference Laboratory (Public Health Laboratory Service), The London Hospital
}

An indirect fluorescent antibody test for the detection of Treponema pallidum in early syphilitic lesions was first described by Edwards (1962); syphilitic serum was used as a source of antibody. The demonstration of the sharing of common antigens between $T$. pallidum and other pathogenic and commensal treponemes by Deacon and Hunter (1962) established the need for removal of such group reactive antibody from syphilitic serum to permit the detection of antibody specific for $T$. pallidum. Methods for attempting this have been the dilution of serum (Garner and Robson, 1968a), absorption of serum with Reiter treponemes (Jue, Puffer, Wood, Schochet, Smartt, and Ketterer, 1967; Kellogg and Mothershed, 1969; Kellogg, 1970), with the sorbent used in the FTA-ABS test (Garner and Robson, 1968b), or by blocking cross-reactivity by dilution of the conjugated syphilitic globulins with an anti-Reiter serum conjugated with Rhodamine, this also providing a counterstain (Danielsson, Johannisson, and Hederstedt, 1970). Satisfactory results have been reported by all these methods in comparison with the conventional darkground technique.

\section{Material and methods}

After the lesion had been cleansed, a drop of exudate was spread thinly within a $1 \mathrm{~cm}$. diameter circle on a carefully cleaned microscope slide. On receipt in the laboratory the slide was fixed in fresh acetone for $10 \mathrm{~min}$. An indirect FA staining technique was used. The antiserum was hightitred syphilitic human or rabbit serum which had been absorbed with intact or ultrasonically disintegrated Reiter treponemes to remove group reactivity. Particulate matter was removed by centrifugation and passage through a Millipore filter, pore diameter $0.22 \mu$. The absorbed serum gave no fluorescence with Reiter treponemes or four strains of commensal genital treponemes and two strains of oral treponemes which had been isolated in the laboratory. It was used at the greatest dilution in phos-

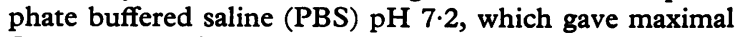
fluorescence with $T$. pallidum as antigen. Diluted antiserum was applied to the fixed smear for $30 \mathrm{~min}$. at $35^{\circ} \mathrm{C}$., followed by two washes each of $5 \mathrm{~min}$. duration in PBS and a rinse in distilled water. When dry, the appropriate fluorescein-conjugated anti-species immunoglobulin diluted to its optimum titre in PBS was applied for $30 \mathrm{~min}$. at $35^{\circ} \mathrm{C}$., followed by a similar washing procedure. When dry, the slides were mounted in buffered glycerin, $\mathrm{pH} 7 \cdot 2$.

Received for publication March 24 :1971
Controls for each set of slides examined were fixed films of $T$. pallidum (Nichols strain) and Reiter treponemes. These control slides were processed in separate containers to avoid accidental transfer of treponemes to the test slides.

Slides were examined by darkground illumination, either with an HBO 200 light source with a $3 \mathrm{~mm}$. BG 12 exciter filter and Zeiss 53/44 barrier filters or with quartz iodine illumination with a Rygaard and Olsen (1969) interference filter and a matched 530 barrier filter. The latter form of illumination was preferred, as the controllable amount of red light passed lessened the background fluorescence and gave an excellent optical contrast. Suspected organisms were also examined under visible light. Results were accepted as positive only if brightly fluorescing treponemal forms were seen with definite spirals and with characteristic refractility under visible light. Treponemal morphology was usually well preserved in the fixed specimens (Fig. 1).

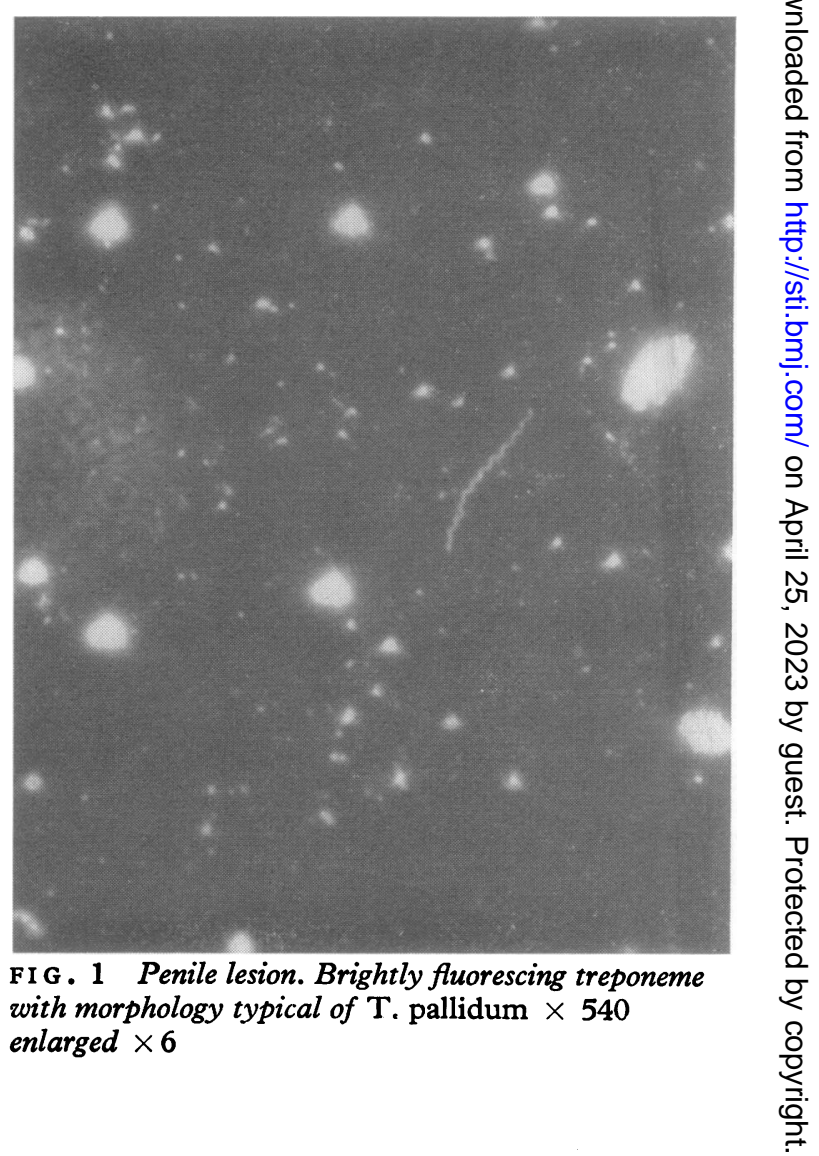




\section{Results}

81 specimens were examined from 76 patients, all but eight of whom were males. Smears were prepared from lesions of the penis or scrotum in 52, the anorectal region in eight, the vulva in five, the lip in four, the skin in three, and from fluid obtained by gland puncture in nine. Direct darkground examinations were performed in the Whitechapel Clinic on all but seven of these specimens. The results of FA staining and direct darkground examination are compared in Table I and correlated with the serological and epidemiological evidence of treponemal infection in Table II.

TABLE II Correlation of results of staining with serological and epidemiological evidence of syphilis in 81 cases

\begin{tabular}{|c|c|c|c|}
\hline \multirow{2}{*}{$F A$ result } & \multirow{2}{*}{$\begin{array}{l}\text { Darkground } \\
\text { result }\end{array}$} & \multicolumn{2}{|c|}{ Evidence } \\
\hline & & Present & Absent \\
\hline Positive & Positive & 17 & 4 \\
\hline Positive & Negative & 2 & 1 \\
\hline Positive & Not done & 2 & 0 \\
\hline Suspicious & Negative & 2 & 0 \\
\hline Negative & Negative & 9 & 36 \\
\hline Negative & Suspicious & 1 & 2 \\
\hline Negative & Not done & 1 & 4 \\
\hline Total & & 34 & 47 \\
\hline
\end{tabular}

Treponemes were found by FA staining in 26 specimens and the result was regarded as suspicious but not definite in a further two. All but five of these came from patients with serological or epidemiological evidence to substantiate the findings; this was also true of the two suspicious results. Typical treponemes had been found by direct darkground examination in four of the five cases in which supporting evidence was lacking. The conventional darkground was read as suspicious on three specimens; two of these patients had lesions of the lip and no treponemes were seen by FA staining. The third was a patient with secondary syphilis and strongly positive serological tests whose consort was also darkground-positive; no treponemes were found by FA staining of a smear from a peri-anal lesion.

The results obtained in this study confirm those of previous workers and suggest that the demonstration of treponemes from early lesions by FA staining is a useful alternative to the conventional darkgroundo method of examination. Although the movements $\frac{\overline{ }}{\bar{N}}$ characteristic of $T$. pallidum cannot be evaluated in $\frac{\bar{T}}{7}$ fixed smears, FA staining introduces an element of $\mathbb{Q}$ immunological specificity into the reaction. $A b-\triangleq$ sorption of the antisera used for these tests with $\overrightarrow{ }$ Reiter treponemes removed reactivity with this organism and with a number of recently isolated $\vec{\omega}$ genital and oral strains of treponemes. Whether this procedure is adequate to remove group-reactive $\stackrel{?}{=}$ antibody to all strains of commensal treponemes $\overrightarrow{ }$ inhabiting the genital tract or oral cavity is not yet established. It is also possible that these commensals of may lose antigens on cultivation which they possess ${ }^{N}$ when growing in vivo. On several occasions non-은 fluorescing treponemes were seen in the stainedsmears, their morphology differing from that of $T$. pallidum (Figs 2 and 3).

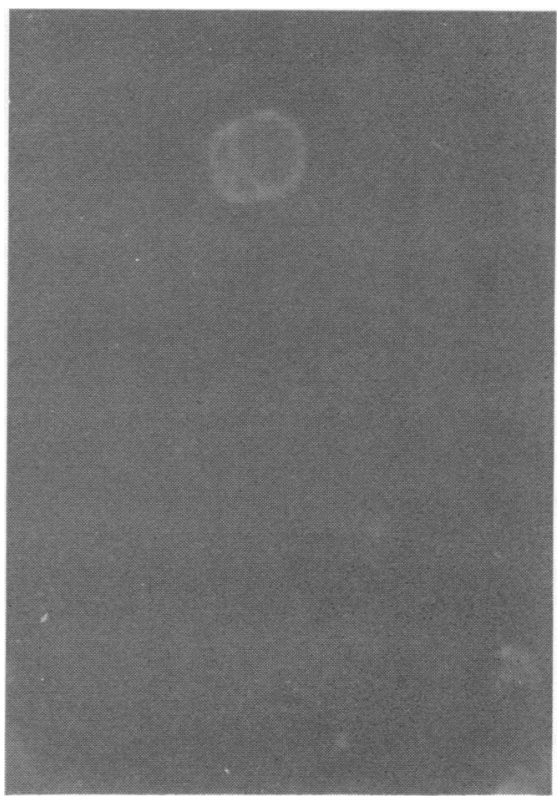

FI G. 2 Penile lesion. Taken under $u / v$ light. No fluorescent treponemes visible. $\times 540$ enlarged $\backslash 6$

TABLE I Comparison of darkground and FA staining on 81 specimens

\begin{tabular}{|c|c|c|c|c|c|}
\hline \multirow{2}{*}{$F A$ result } & \multicolumn{5}{|c|}{ Darkground result } \\
\hline & Positive & Suspicious & Negative & Not done & Total \\
\hline $\begin{array}{l}\text { Positive } \\
\text { Suspicious } \\
\text { Negative }\end{array}$ & $\begin{array}{r}21 \\
0 \\
0\end{array}$ & $\begin{array}{l}0 \\
0 \\
3\end{array}$ & $\begin{array}{r}3 \\
2 \\
45\end{array}$ & $\begin{array}{l}2 \\
0 \\
5\end{array}$ & $\begin{array}{r}26 \\
2 \\
53\end{array}$ \\
\hline Total & 21 & 3 & 50 & 7 & 81 \\
\hline
\end{tabular}




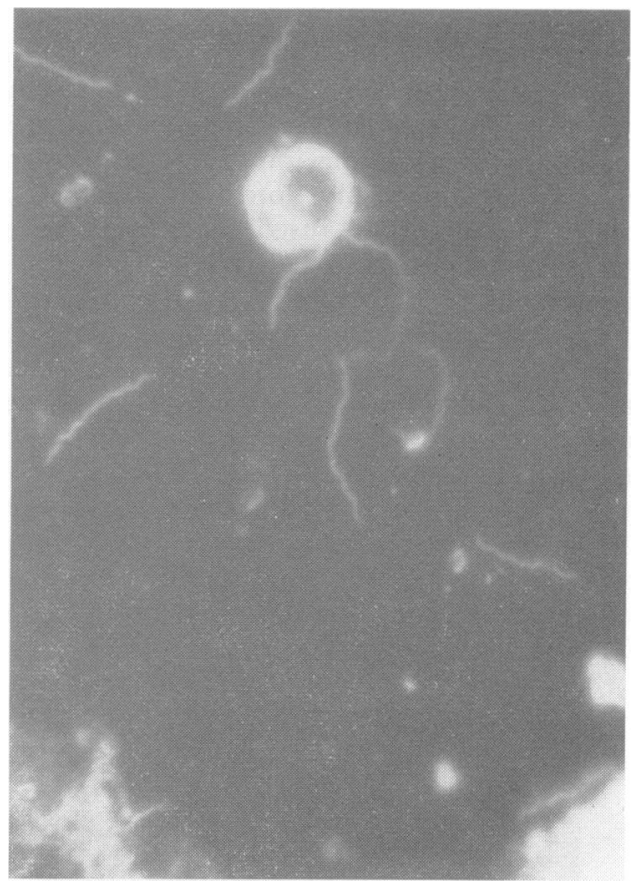

FI G. 3 Same field as Fig. 2, taken under visible light. Numerous non-fluorescing treponemes present. $\times 540$ and enlarged $\times 6$

The FA staining technique should prove valuable as a confirmatory measure when the results of conventional darkground examination are equivocal or when specimens from the mouth have to be examined, as some of the commensal treponemes inhabiting this site, such as $T$. microdentium, may closely resemble $T$. pallidum. It should also permit the taking of specimens when facilities for immediate darkground examination are not available.

\section{Summary}

The results of indirect fluorescent antibody staining and conventional darkground examination for $T$. pallidum on 81 specimens from suspected early syphilitic lesions are compared. The IFA technique with a suitably absorbed antiserum is thought to be a useful adjunct to ordinary darkground examination, particularly when the latter gives inconclusive results.

We wish to thank Dr. N. R. W. Perera for supplying strains of commensal treponemes, Dr. P. Rodin for his interest and help in obtaining specimens for examination, and Mr. G. W. Lavender, A.I.M.L.T., for the photographs. We are also grateful to the World Health Organization for a grant.

\section{References}

Danielsson, D., Johannisson, G., and Hederstedt, B. (1970) Acta path. microbiol. scand., 78, Sect. B. (Microbiol. and Immunol.), p. 267

Deacon, W. E., and Hunter, E. F. (1962) Proc. Soc. exp. Biol. (N.Y.), 110, 352

EdWARds, E. A. (1962) Publ. Hlth Rep. (Wash.), 77, 427

Garner, M. F., and Robson, J. H. (1968a) F. clin. Path., 21, 108

-,- (1968b) Ibid., 21, 576

Jue, R., Puffer, J., WOOd, R. M., Schochet, G., SMartT, W. H., and KetTerer, W. A. (1967) Amer. F. clin. Path., 47, 809

KeLLOGG, D. S. (1970) Hlth Lab. Sci., 7, 34 and Mothershed, S. M. (1969) f. Amer. med. Ass., 207, 938

RygaARD, J., and Olsen, W. (1969) Acta path. microbiol. scand., 76, 146

\section{La coloration par immuno-fluorescence pour la détection du Treponema pallidum dans les lésions syphilitiques récentes}

\section{SOMMAIRE}

Dans 81 specimens de lésions suspectes d'être syphilitiques récentes, on compare les résultats du marquage, par la méthode indirecte, à l'anticorps fluorescent, avec l'examen classique au fond noir. La technique indirecte à l'anticorps fluorescent, lorsque l'on dispose d'un antisérum absorbé convenable, est considérée comme constituant un appoint utile à l'examen ordinaire au fond noir; en particulier lorsque celui-ci donne des résultats douteux. 